\title{
Urdimento
}

Revista de Estudos em Artes Cênicas

E-ISSN: 2358.6958

\section{Sobre cartas, celas, elas e professoras-em-processo}

Daiane Dordete Stecket Jacobs

Samira Sinara Souza

\section{Para citar este artigo:}

JACOBS, Daiane Dordete Stecket; SOUZA, Samira Sinara. Sobre cartas, celas, elas e professoras-emprocesso. Urdimento, Florianópolis, v. 3, n. 39, nov./dez. 2020.

DOI: http:/dx.doi.org/10.5965/14145731033920200108

Este artigo passou pelo Plagiarism Detection Software | iThenticate 


\title{
Sobre cartas, celas, elas e professoras-em-processo
}

\author{
Daiane Dordete Stecket Jacobs ${ }^{1}$ e Samira Sinara Souza ${ }^{2}$
}

\begin{abstract}
Resumo
Nestas cartas escritas a quatro mãos busca-se rememorar e refletir sobre o trabalho desenvolvido pelas autoras com mulheres em privação de liberdade no Presídio Regional de Joinville (PRJ). Do projeto inicial de pesquisa e montagem da peça celas em 2010, a partir de narrativas de mulheres em situação de cárcere e egressas do PRJ, às oficinas de teatro realizadas com estas mulheres anos depois - intercaladas pelas apresentações da peça em sua primeira versão e sua posterior desmontagem -, procura-se tecer os fios que trouxeram a este lugar de atuação e análise. Através de uma escrita performativa, mesclam-se memórias e afetos das artistasprofessoras com narrativas e reflexões sobre o processo pedagógico desenvolvido no segundo semestre de 2019 no PRJ, a partir de uma perspectiva de gênero. Confidenciam-se desejos, incertezas, descobertas, frustrações e conquistas que este percurso trouxe, tendo como foco a percepção da docência como um processo criativo constante e dialógico, de professoras-em-processo.
\end{abstract}

Palavras-Chave: Pedagogia do teatro. Teatro com mulheres em privação de liberdade. Professoras-em-processo. Teoria crítica feminista.

${ }^{1}$ Profa. Dra. Associada do Departamento de Artes Cênicas da UDESC - Universidade do Estado de Santa Catarina, na área de voz/interpretação, e do Programa de Pós-graduação em Teatro da UDESC. Diretora de Extensão, Cultura e Comunidade do Centro de Artes da UDESC (gestão 2017-2021). Doutora e Mestra em Teatro pela UDESC. Bacharela em Artes Cênicas com habilitação em Interpretação Teatral pela FAP Faculdade de Artes do Paraná (UNESPAR). Editora Associada da Revista de Estudos em Artes Cênicas URDIMENTO (PPGT/UDESC) e da Revista VOZ E CENA (PPGACEN/UnB). daiane.jacobs@udesc.br

${ }^{2}$ Atriz/performer, pesquisadora, produtora cultural e executiva da VAl! coletivo de pesquisa cênica desde 2009. Mestra em Patrimônio Cultural e Sociedade pela Universidade da Região de Joinville- UNIVILLE. Especialista em Fundamentos do Ensino do Teatro pela Faculdade de Artes do Paraná- FAP (UNESPAR) e Licenciada em Educação Artística (Artes Plásticas) pela Universidade da Região de Joinville - UNIVILLE. Autora do livro "A Casa №909 da Rua XV de Novembro: Espaço praticado de memórias em Joinville/SC". samira.sinara@hotmail.com 
Regarding letters, cells, them and teachers-in-process

\begin{abstract}
These letters, written by two authors, commemorate and reflect on the work developed by the authors with incarcerated women at the Presidio Regional de Joinville (PRJ). The texts document the initial research project and mounting of the play celas in 2010, created from narratives of women in prison and those released from PRJ, as well as the theater workshops held with these women years later. This is interspersed with scenes from the play in its first version and later production. This text weaves together the threads of acting and analysis. Through performative writing, it seeks to mix memories and feelings of artist-teachers with narratives and reflections on the pedagogical process developed in the second half of 2019 at PRJ, from a gendered perspective. The paper divulges the hopes, uncertainties, discoveries, frustrations and achievements that this path has brought, focusing on the perception of teaching as a constant and dialogical creative process, of teachersin-process.
\end{abstract}

Keywords: Theatre pedagogy. Theatre with women in deprivation of liberty. Teachers-in-process. Feminist critical theory.

Sobre cartas, celdas, ellas y maestras-en-proceso

\title{
Resumen
}

Estas cartas, escritas a cuatro manos, tratan de recordar y reflexionar sobre el trabajo que desarrollan las autoras con mujeres en privación de libertad en el Presidio Regional de Joinville (PRJ). Desde el proyecto de investigación inicial y montaje de la obra teatral celas en 2010, desde las narrativas de mujeres en prisión y egresadas del PRJ, hasta los talleres de teatro realizados con estas mujeres años después - intercalados con presentaciones de la obra en su primera versión y posterior desmontaje -, intentamos tejer los hilos que nos llevaron a este lugar de actuación y análisis. A través de una escritura performativa, buscamos fusionar los recuerdos y afectos de las artistas-maestras con narrativas y reflexiones sobre el proceso pedagógico desarrollado en el segundo semestre de 2019 en el PRJ, desde una perspectiva de género. Compartimos deseos, incertidumbres, descubrimientos, frustraciones y logros que nos ha traído este camino, enfocándonos en la percepción de la docencia como un proceso creativo constante y dialógico, de maestras-enproceso.

Palabras clave: Pedagogía teatral. Teatro con mujeres privadas de libertad. Maestrasen-proceso. Teoría crítica feminista. 
Carta da atriz-professora-produtora (Joinville, jan./2017)

Oi Dai, tudo bem com vocês? Já se mudaram? Quem sabe este ano dê certo a minha visitinha aí. Te contei que estou na presidência da AJOTE? É uma luta manter as conquistas que a associação de teatro da cidade já teve né... a cada troca de gestão municipal não sabemos o que será das políticas culturais, das artistas, da arte. Na semana retrasada fui a uma reunião com os responsáveis pela Cidadela Cultural Antarctica ${ }^{4}$, porque estamos sem luz e sem banheiro público por lá há mais de três meses e um órgão joga para o outro a responsabilidade de não fazer nada. Enfim, na última reunião consegui unir os dois órgãos que respondem pelo patrimônio, e passei por uma situação no mínimo estranha: o representante do órgão público que recebeu a mim e às outras pessoas presentes na reunião me cumprimentou por último. Até aí, tudo bem. Mas ele cumprimentou todos os homens presentes na reunião e eu, a única mulher ali, fui a última a ser cumprimentada, quase sendo ignorada, apesar de ter sido a primeira a entrar na sala. Na hora não me atentei à atitude machista, só quando cheguei em casa e fiquei recordando desta e de outras situações que ocorreram na reunião. Fiquei pensando o quanto nós, mulheres, ainda somos caladas na tentativa de nos manterem "belas, recatadas e do lar". Isso me fez lembrar da nossa peça celaš, especialmente da frase: "Às vezes, é preciso morrer para viver de novo. Matar a antiga mulher que me habitou é meu dever. Não quero ser outra, só quero ser" (Jacobs, 2011). Como o processo de criação e as apresentações do celas nos fizeram questionar e procurar rotas de fuga das nossas prisões sociais, políticas e

\footnotetext{
${ }^{3}$ Associação Joinvilense de Teatro - AJOTE.
}

${ }^{4}$ Espaço público onde está situado o galpão de teatro da AJOTE.

5 O solo performático celas foi criado a partir de duas pesquisas de iniciação científica, utilizando a metodologia da história oral, realizadas por Camila Diane Silva no curso de História da Universidade da Região de Joinville (UNIVILLE). A primeira, de 2007, entrevistou mulheres em situação de cárcere no PRJ, e a segunda, de 2009, entrevistou egressas desse sistema. O solo buscou não focar na representação destas narrativas, criando uma dramaturgia original que abordou paradigmas sociais, desejos, conflitos, preconceitos e estigmas sofridos por mulheres em nossa sociedade, advindos das relações de opressão e construções históricas de gênero. A peça tinha uma proposta estética poética e não-linear, calcada na performatização da atuação e nas relações polifônicas e dialógicas dos signos do espetáculo. Foram realizadas mais de cinquenta apresentações da peça em festivais, mostras e na circulação promovida pelo SESC-SC, Encena Catarina. A montagem foi realizada através do Edital de Apoio à Cultura de Joinville de 2010, projeto “Crimes, celas e elas: mulheres e cárcere”, proponente Samira Sinara Souza. 
culturais, né amiga?! Ainda está latente em mim o que construímos e vivenciamos ao longo desses sete anos. Hoje não consigo mais aceitar calada essas situações comigo e com outras mulheres. Mas dei a minha resposta, Dai... fui a única a dar solução ao problema da Cidadela e todos aceitaram, inclusive ele.

Depois destes dois anos que deixamos o celas adormecido, fiquei com vontade de retomar o projeto, talvez com outro enfoque, com um olhar mais direcionado às mulheres que estão no espaço prisional. Lembro do pouco acesso à arte e à cultura que elas relataram ter em conversas nos corredores do PRJ e nos bate-papos que fizemos após a apresentação do celas lá, no Dia Internacional da Mulher, em 2012. Nunca havia entrado em um espaço de encarceramento e recordo de falas como: "nunca tinha visto uma peça de teatro" ou "eu gostei mais da cena da mãe". Para nós foi uma apresentação em data simbólica, como forma de lembrar e ratificar as lutas por igualdade de gênero e o combate às violências que sofremos diariamente. Naquele dia, com 32 graus em Joinville, estávamos sem água e sem sombra, e nos deparamos no pátio com a imensidão laranja dos uniformes das mulheres encarceradas, e com homens com metralhadoras por todos os lados. A ansiedade tomou conta de nós. No decorrer da apresentação, observamos rostos em lágrimas, risadas, emoções... Afinal, esse é o papel da arte! Destroçar e humanizar em poucos minutos através de corpos, movimentos, palavras, imagens, vozes e sons... pela partilha do que há de mais sagrado em nós. O presente maior foi a contribuição do sol como iluminação natural da peça, já que não pudemos levar projetor, mesa de luz e refletores... acho que a cena com aquele feixe de sol atravessando o teto do pátio proporcionou para as mulheres que nos assistiam um momento de maior intimidade com elas mesmas.

Pensando em tudo isso, aproveitei e fiz recentemente uma pesquisa sobre as atuais circunstâncias do PRJ, já que não piso lá há cinco anos. Pasme, as mulheres ainda não possuem espaço prisional adequado, ou seja, se encontram no ‘puxadinho' das galerias masculinas. Não sei a quantidade exata de mulheres neste

${ }^{6}$ Relatos e depoimentos de mulheres em privação de liberdade do Presídio Regional de Joinville coletados pela atriz Samira Sinara Souza após uma apresentação de celas no dia 08/03/2012. Público estimado de 50 mulheres, agentes carcerárias, integrantes do Centro de Direitos Humanos Maria da Graça Bráz e do Conselho Carcerário de Joinville. 
momento no presídio, mas eu li no livro da Juliana Borges (2019) que houve um aumento brutal de mulheres presas entre os anos de 2006-2014 no Brasil, 567,4\%! Alarmante esse dado! Adivinhe qual o crime mais cometido? Tráfico de drogas. Se a mulher livre já sofre o preconceito diário por ser mulher, imagine a mulher presa, mãe, esposa, namorada de traficante... Quantas ali não são apenas usuárias? Eu fico aqui pensando, nós mulheres menstruamos todo mês e damos a luz a seres humanos, e como não há espaço adequado nas prisões para garantir a sobrevivência e a dignidade humanas ${ }^{7}$ ? Penso nisso muito a partir das reflexões da Juliana Borges nesse livro que citei, Encarceramento em Massa. Ela faz uma análise com perspectiva de gênero, raça e classe dos processos punitivos no Brasil, demonstrando como o racismo, a misoginia e o elitismo prevalecem no sistema penal. E a Lei de Drogas $^{8}$ só fez piorar a situação das mulheres e das pessoas negras, superlotando presídios com pessoas que aguardam julgamentos que determinarão se elas eram usuárias de drogas ou traficantes de drogas. E a pergunta que a Juliana Borges faz é assertiva e contundente:

Quais são as chances de uma mulher negra, com uma pequena quantidade de substância ilícita, ser considerada traficante e não usuária? Quais as influências sociais, políticas, territoriais, raciais e de gênero para a definição dessa diferenciação? Eu respondo: todas as influências. (Borges, 2019, p. 102).

Dai, metade dessas mulheres são mães, e poderiam estar em prisão domiciliar ao invés de prisão preventiva... e por que não estão, se a legislação ${ }^{9}$ permite? Só o racismo, o machismo estruturais (e institucionais) e o elitismo explicam isso... é só lembrar dos escândalos recentes de corrupção envolvendo mulheres brancas de políticos, que rapidamente conseguiram liminar para aguardar o julgamento em prisão domiciliar... revoltante!

A sensação parece de ser jogada como lixo, em um depósito humano... não

${ }^{7}$ Cf. Cerneka, 2009.

${ }^{8}$ Lei Federal n.11.343, de agosto de 2006

${ }^{9}$ Marco Legal da Atenção à Primeira Infância, 2016. 
é à toa que os espaços prisionais, hospitais psiquiátricos e os 'lixões' são construções localizadas geralmente longe dos centros urbanos. Que tristeza! E para piorar a sociedade em que estamos inseridas ainda não percebeu (ou não quer perceber) os reflexos estarrecedores dessa discriminação: preconceito social e abandono do Estado. A sociedade ainda não reconhece a ressocialização. Não é à toa que, por esses motivos, muitas mulheres reincidem nas infrações, pois não encontram mais espaço em uma sociedade que faz questão de lhes excluir.

Teremos ainda muito o que lutar para derrubar essas estruturas injustas e nos libertar dessas amarras em todas as instâncias, ainda mais dentro das prisões, esses espaços complexos e punitivos. No teatro também temos nossas lutas, né Dai... A Elza Cunha de Vincenzo, no livro Um Teatro da Mulher, contextualiza a emergência de diversas dramaturgas nos palcos brasileiros da segunda metade do século XX, e diz assim: “[...] a mulher tomara a palavra e de algum modo rompera o silêncio para falar do mundo e de si mesma, ela tinha sido ao longo do tempo, preferencialmente, objeto do discurso masculino e não sujeito de seu próprio discurso" (Vicenzo, 1992, p. 21). Quando li lembrei de você, porque ela argumenta sobre o fato de pouquíssimas mulheres assumirem esse protagonismo autoral de peças teatrais na história do teatro, por ser um espaço historicamente masculino. O teatro, através dos jogos teatrais, improvisações e dramaturgias pode propiciar também às mulheres em privação de liberdade esse encontro crítico com seus contextos sociais. Por isso estou tão interessada em escrever esse projeto de oficinas de teatro para as mulheres do PRJ!

Lembra uma vez, em uma apresentação do celas em uma cidade do interior de Santa Catarina, que uma mulher entrou no camarim e me abraçou emocionada após a peça? Ela disse que vivia em uma cidade muito machista, e que quando saiu da cidade foi muito mal falada porque tinha fugido para se casar com alguém que ela gostava muito, e era bem mais velho que ela. Mais tarde ela teve que retornar à cidade porque o relacionamento acabou e continuou sendo mal falada, e não aguentava mais viver da mesma forma naquela mesma cidade. Pensando nela, eu sempre me perguntava quando terminava alguma apresentação: qual a diferença entre essa espectadora (livre) e uma mulher presa? Essa espectadora 
tinha compreendido o nosso foco de crítica na peça, de denúncia de preconceitos e estigmas advindos das relações de gênero e construções culturais a respeito da mulher. E é uma grande alegria presenciar nesta e em outras mulheres esse despertar da consciência crítica para a sua própria existência, né? Essa percepção que se expande pras relações que tecemos na vida, que são reflexos de opressões históricas, de diferenças contextuais, e nunca apenas fruto das ações individuais... A responsabilidade por uma vida melhor, mais justa e igualitária para todas é de toda a sociedade.

Quando eu estava estudando Mestrado em Patrimônio Cultural e Sociedade fui muito questionada por ser artista e estar no curso, buscando um tema diferenciado da minha profissão. Nesse percurso conheci o historiador Michel de Certeau, que em vários momentos das suas obras me lembrava o quanto a arte consegue transpor e transformar o eu e o outro através do discurso. Há uma frase dele bem interessante, que diz assim:

Os lugares são histórias fragmentárias e isoladas em si, dos passados roubados à legibilidade por outro, tempos empilhados que podem se desdobrar... permanecem no estado de quebra-cabeças, enigmas, enfim, simbolizações enquistadas na dor ou no prazer do corpo." (Certeau,1994, p.189).

Ou seja, através de lugares materializados, como o cenário do celas e o espaço teatral, a espectadora vivencia nas cenas sua própria história, podendo se identificar com a obra, se colocar em diálogo com ela, e alterar posteriormente o seu próprio discurso.

Agora, imagina Dai... as mulheres em privação de liberdade, ao estarem inseridas em lugares com inúmeras pessoas, dividem quantas histórias que se tornam símbolos de esperança, de dor, de revolta? Nós poderíamos pensar em um modo de ajudar essas histórias a se projetarem para além das grades, através do teatro... vamos pensar nesse projeto?

Amiga, só não sei se teremos fôlego de montar e desmontar aquele andaime várias vezes (risos). Enfim, já conversei com a VAl!10 e todos aceitaram e 
incentivaram o prosseguimento dos trabalhos do celas, agora com foco nas oficinas de teatro na prisão. Vamos até essas mulheres compartilhar o universo da arte, propiciar o desenvolvimento da imaginação, da criatividade, da coletividade, da cidadania, da consciência crítica e de tudo o mais que a arte e a educação podem proporcionar! E vamos pensar também em como poderíamos retomar o celas... Tô empolgada aqui (risos)! Será importante para todas nós... agora serão celas e elas.

Espero o seu retorno em breve, pois o Edital de Apoio à Cultura de Joinville já está com inscrições abertas (apesar de estar atrasado).

Saudades. Te envio algumas fotos pra te inspirar...

Abraços cênicos da sua atriz, Sá.

Figura 1 - Apresentação da peça celas no PRJ, 08 mar. 2012. Foto: Nilton Tirotti

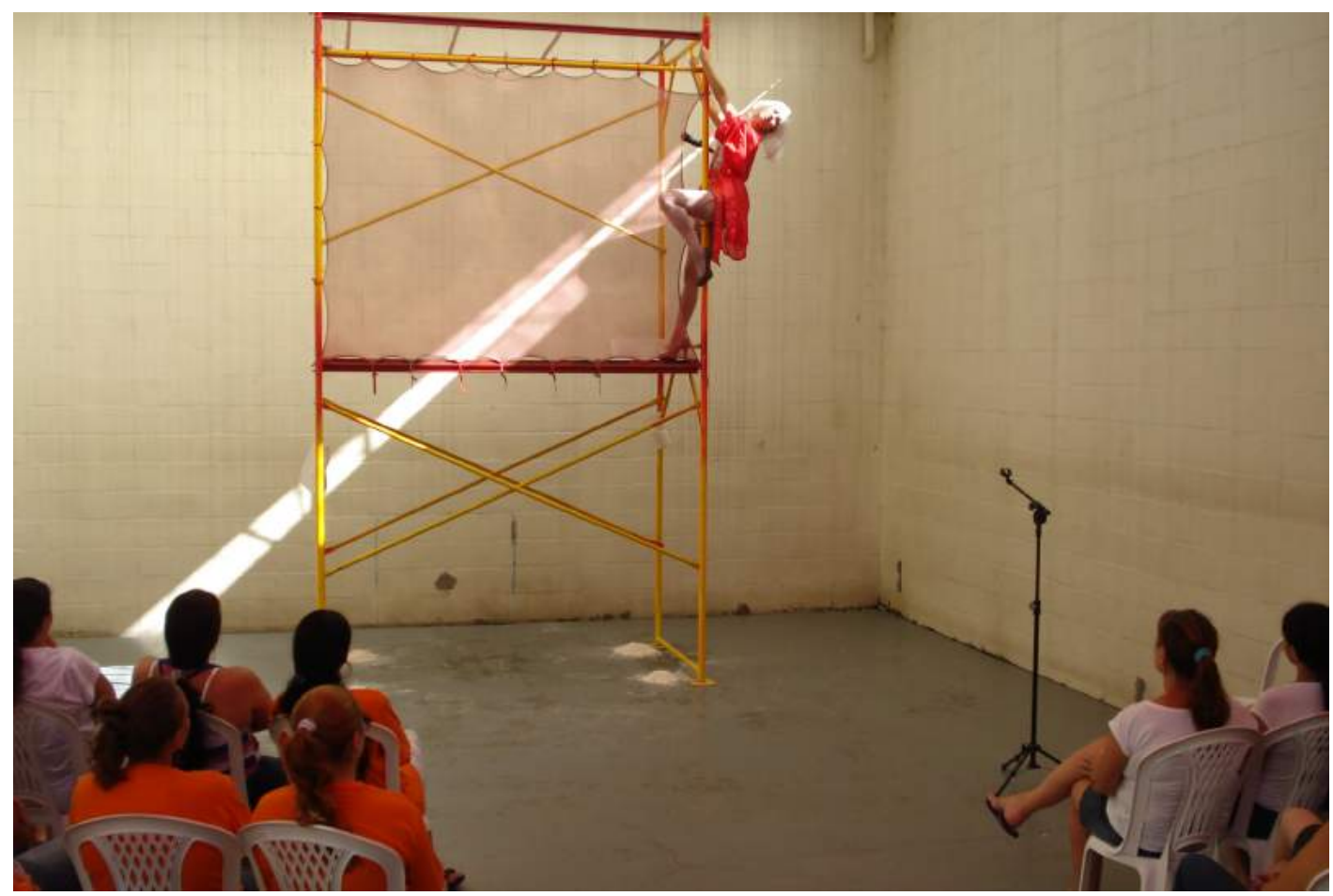

dramatização e olhar próprio, com o diálogo da representação na performance resultando em obras de arte que reflitam uma forma de sentir, ver, agir e pensar na construção de uma sociedade mais democrática, justa e igualitária. Maiores informações nas plataformas digitais: https://www.facebook.com/vaicoletivodepesquisacenica,(página no facebook), @vaicoletivo (Instagram) e https://www.youtube.com/channel/UCPew4oZjUkU7o3h5yynKxwQ (canal You Tube). 
Figura 2 - Apresentação da peça celas no Cena 9 Mostra de Teatro Joinvilense Galpão de Teatro da Ajote, 2012. Foto: Mello e Ronsani

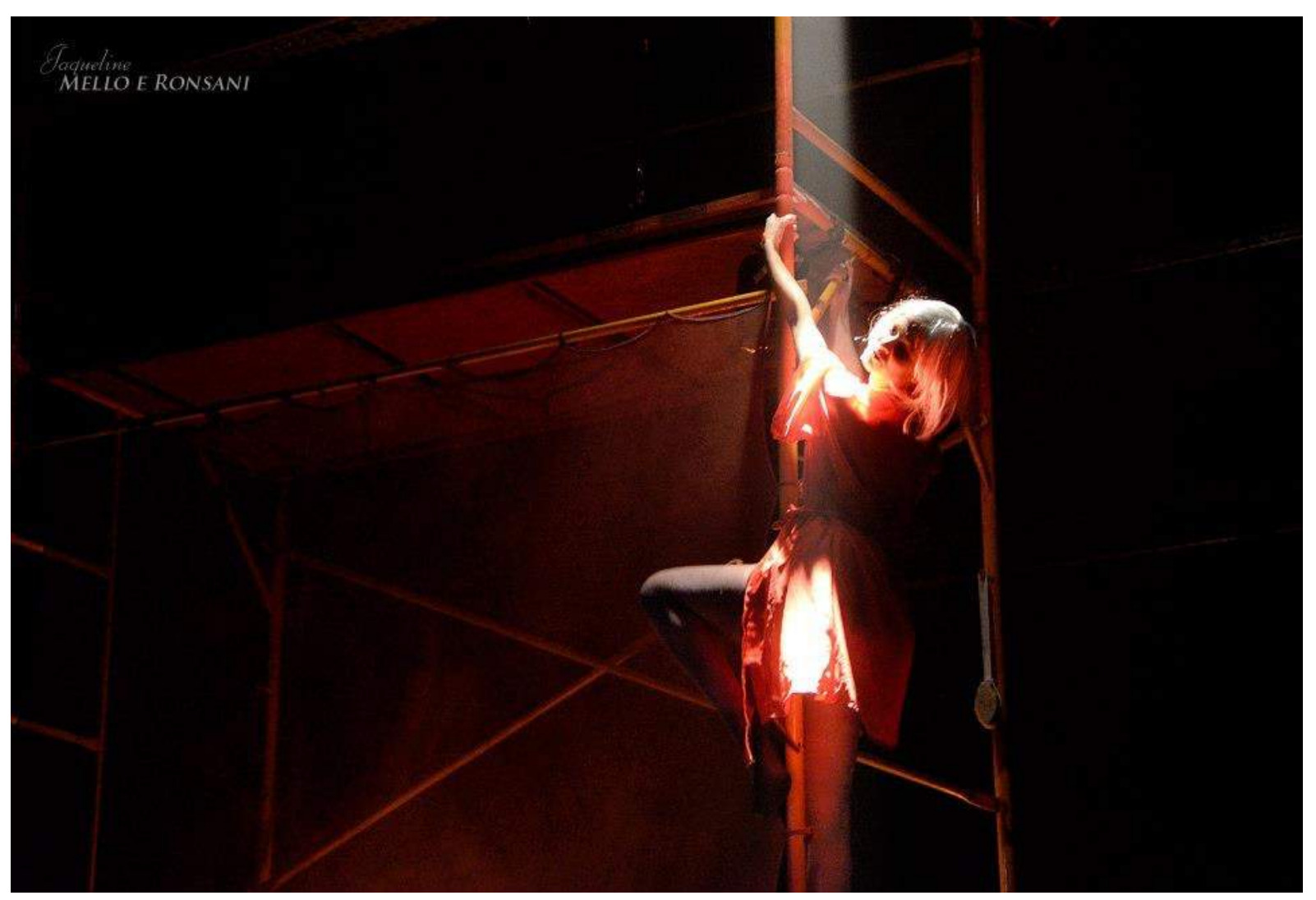

Carta da diretora-dramaturga-professora (Florianópolis, maio/2019)

Porém, confesso que estou bem cansada das idas e vindas de Florianópolis a Joinville semanalmente para as aulas de teatro"1 no PRJ. Não imaginei que um semestre na estrada me deixaria tão exausta... é que não temos mais os 20 anos de quando nos conhecemos, não é mesmo? E também somos engolidas pelas diversas demandas da casa e das outras atividades de trabalho... é a precarização da vida causada pelo capitalismo que consome nossos corpos.

Pois bem, estou aqui pensando em como poderíamos encaminhar a finalização das oficinas com as mulheres em privação de liberdade do PRJ. Vim

${ }^{11}$ Oficinas de Teatro realizadas com 02 turmas de mulheres em privação de liberdade do Presídio Regional de Joinville-SC, durante os meses de fevereiro a junho de 2019, por meio do Edital de Apoio à Cultura de 2016, do Sistema de Desenvolvimento pela Cultura de Joinville-SC. Projeto: Celas e elas - teatro com mulheres em privação de liberdade. Proponente: Samira Sinara Souza. 
reler o projeto inicial das oficinas, as anotações das aulas e os e-mails que trocamos neste semestre para tentar ativar tantas memórias e reflexões que nos acompanharam nesses anos.

Encontrei até um e-mail bem antigo teu, lá dos idos de 2017, quando estávamos desenhando esse novo projeto com as aulas... quanta luta né amiga? Naquele ano o edital de cultura já estava atrasado, o desmonte do sistema de desenvolvimento pela cultura de Joinville estava em curso, e nós assistíamos estarrecidas esse retrocesso... mal imaginávamos as dificuldades que nos esperavam para realizar as oficinas de teatro com as mulheres na prisão: falta de espaço adequado para as aulas, falta de priorização de aulas para as mulheres, falta de interesse em arte e cultura por parte da administração prisional... fizemos tantas reuniões, foram tantos adiamentos, tantas explicações... mas, enfim, chegamos aqui, quase no fim do primeiro semestre de 2019, e estes encontros semanais com elas me lembram o porquê escolhi ser professora e artista!

Sabe, esse projeto me trouxe mais fortemente a percepção da docência como um processo criativo constante, um work-in-process. Apesar de sempre encarar os processos de ensino-aprendizagem por esta perspectiva, foi na condução de processos pedagógicos com adolescentes em vulnerabilidade socioeconômica'12 e mulheres em privação de liberdade que esta diretriz se impôs de modo mais determinante para mim, porque apesar de toda a pesquisa e planejamento que fazemos, é a realidade concreta e imediata da vida subjugada e privada de direitos básicos que determina os caminhos da aula a cada encontro.

Lembra de quantas vezes alteramos rapidamente nossa proposta de aula, ao ver as alunas chateadas com algo, ouvir suas histórias cômicas dos causos do "xis"13 ou suas indignações? Percebemos que às vezes elas precisavam muito mais de uma escuta ativa, tanto para suas narrativas quanto para seus desejos de ação em aula. Às vezes elas queriam só conversar com colegas que viam pouco, falar

\footnotetext{
12 Projeto "Oficinas de teatro contemporâneo", realizadas através do Edital de Apoio à Cultura 2010, do Sistema de Desenvolvimento pela Cultura - SIMDEC, de Joinville-SC. As oficinas foram desenvolvidas com adolescentes de dois Centros de Referência em Assistência Social (CRAS) de bairros periféricos da cidade.

${ }^{13}$ Gíria utilizada pelas mulheres do PRJ para se referirem às suas celas.
} 
sobre as visitas, as saudades e as ausências. Às vezes elas queriam jogos divertidos, queriam rir umas com as outras! E outras vezes era só cansaço mesmo, calor, desconforto, coisas que a nossa "cela de aula"14 não ajuda a superar...às vezes queriam fazer algo que não faziam há muito tempo, como o dia em que pediram pra ver um filme e comer pipoca, lembra? Foi muito legal, pena que não você não pode vir nesse dia. Assistimos Marquise ${ }^{15}$, comemos pipoca, e aproveitei para falar um pouco sobre História do Teatro e dramaturgia. Foi nesse dia, com a turma da manhã, que descobri que alguns refrigerantes têm acesso proibido na prisão... coitada da turma da manhã... levei coca-cola, porque pediram, mas ficou retida na revista... fiquei triste, porque pipoca com água não é a mesma coisa né? Ainda bem que tive tempo de comprar guaraná para a turma da tarde...

E a música? Como elas gostam de cantar! Está sendo muito bom começar ou terminar as aulas com canções. Sinto que elas se animam e se conectam através das vozes que se agigantam para além do espaço minúsculo que compartilhamos nas aulas. Mesmo porque nossos corpos ficam separados dos delas o tempo todo pelas grades da "cela de aula", mas as vozes essas grades não podem separar. A conexão que estabelecemos quando cantamos e compartilhamos nossas ressonâncias nos ajuda nesta aproximação com as alunas através das grades.

Revendo nossos planejamentos de aula, penso que o que mais funcionou neste espaço de ensino até então desconhecido para nós duas foram os jogos teatrais, os jogos musicais e as canções. Viola Spolin ${ }^{16}$ e Augusto Boal' ${ }^{17}$ foram companhias constantes nesse processo, mas também outros tantos jogos que aprendemos, criamos e recriamos nos anos de formação e prática de teatro. Mas as propostas mais individuais de investigação e criação de cenas acho que não

\footnotetext{
${ }^{14}$ A sala de aula do PRJ divide o espaço das professoras e das alunas por grades.

${ }^{15}$ Filme de 1997, com direção de Véra Belmont. Conta a história da dançarina Marquise, cujo sonho de ser atriz a levou a cruzar os caminhos dos dramaturgos Molière e Racine, que a levaram à corte do Rei Luís XIV da França.

${ }^{16}$ Cf. Spolin, 2008.

${ }^{17}$ Cf. Boal, 2009.
} 
funcionaram tão bem, talvez porque um semestre seja muito pouco para a superação da insegurança gerada pela exposição individual, talvez porque elas gostem mais de se divertir com teatro, ou talvez porque a gente ainda não tenha encontrado o caminho para despertar o interesse por esse tipo de atividade.

Dos exercícios de composição que propusemos, me marcou aquele com objetos... uma das alunas, a que ficou com a bandeja, se observou por muito tempo no reflexo do metal... depois das apresentações individuais, durante as reflexões da turma sobre a prática, ela disse:

Nós não podemos ter espelho aqui. Isso é uma forma de diminuir a gente, de acabar com a nossa autoestima. Como a gente pode ser uma pessoa melhor se a gente nem pode se ver, se a gente acaba esquecendo quem é? Precisamos nos amar para amar outras pessoas ${ }^{18}$.

Foi nesse dia que a Jéssica19 estava lá fotografando, não foi? E aí teve a ideia de tirar fotos e mostrar para elas, para que elas pudessem se ver no quadradinho da câmera digital. Foi emocionante, lembra? Algumas choravam, outras riam, outras pensavam nas marcas que a pele tinha ganhado.

É muito interessante perceber este processo a partir da inversão do olhar: o que nós estamos aprendendo como professoras. Para além de tudo o que o teatro pode proporcionar pedagogicamente - como desenvolvimento da atenção, respeito às regras, sentimento de coletividade, conhecimento e expressão do corpo e da voz, fluência verbal, capital cultural e consciência crítica -, eu percebo que as aulas estão desenvolvendo um empoderamento artístico, no sentido coletivo que a pesquisadora Joice Berth (2018) dá ao conceito de empoderamento. Ela usa o termo para se referir a um grupo social que pode se projetar em outros futuros possíveis e desejados/desejosos de vida, para além do que o passado de opressão the conferiu como estigma. E neste percurso nós duas nos colocamos em processo com elas, não apenas como mediadoras do processo pedagógico, mas sendo transformadas por ele, em uma relação ao mesmo tempo dialógica e

${ }^{18}$ Anotação feita pela professora Daiane Dordete na aula de 05/04/2019.

19 Jéssica Michels, fotógrafa joinvilense que registrou o processo das oficinas de teatro no PRJ. 
dialética. A Biange Cabral (2008), professora aposentada de teatro da UDESC, pesquisou e refletiu muito sobre a figura da professora-artista, que pensa e conduz o processo pedagógico no teatro como um processo artístico, de criação. Mas para além disso, eu nos vejo neste processo com as mulheres do PRJ como professoras-em-processo, imersas no processo criativo da própria docência como um processo aberto, em transformação: um work-in-process ${ }^{20}$. Após cada encontro nos colocamos a pensar no projeto e no percurso trilhado até ali, em seus desejos, desvios e descobertas, para então planejar o encontro seguinte, sabendo que os planos são provisórios e mutáveis, sendo muito mais resultados do encontro com as alunas do que do planejamento previamente elaborado por nós. E nessa trajetória, a escuta, as canções e os jogos têm sido bons companheiros de viagem.

Sá, acho que será mesmo impossível separar esse processo pedagógico do processo de remontagem do celas ${ }^{21}$. Fomos atravessadas pelas aulas, pelas alunas, pelas vivências e pelas narrativas. Mas depois pensamos nisso, vamos focar agora nessa reta final das oficinas!

Eu estava lembrando aqui do dia em que recebemos a visita do Vicente ${ }^{22}$, da Ashley ${ }^{23}$, da Carol $^{24}$, da Naguissa ${ }^{25}$ e da Hanna ${ }^{26}$ no mês de maio. Elas trouxeram

${ }^{20}$ Renato Cohen pesquisou sobre o work in process na cena contemporânea, que para o autor se transforma em poética, o work in progress, "no qual o paralelismo entre o processo e o produto são matrizes constitutivas da linguagem” (Cohen, 2004, p. 02). O trabalho em processo é uma tônica do teatro experimental dos séculos XX e XXI, estando aberto a mudanças e transformações a partir do encontro entre artistas, obra e público.

${ }^{21}$ Em julho de 2019 estreou em Joinville-SC a peça celas e elas - desmontagem teatral sobre mulheres e cárceres, como desdobramento da montagem inicial da peça celas, em 2011 e das oficinas de teatro realizadas com as mulheres do PRJ em 2019. No artigo "CELAS E ELAS - desmontando cenas e construindo lugares de fala e escuta no teatro feminista" (no prelo) a diretora e dramaturga Daiane Dordete aborda o processo criativo dessa desmontagem teatral e perfopalestra, a partir de reflexões disparadas pelo processo pedagógico das oficinas de teatro com as mulheres do PRJ.

22 Vicente Concílio, professor da UDESC, coordenador do programa de Extensão Pedagogia do Teatro e Processos de Criação, que desenvolve oficinas de teatro no Presídio Feminino e no Centro de Atendimento Socioeducativo de Florianópolis.

${ }^{23}$ Ashley Lucas, professora da Universidade de Michigan, coordenadora do Prision Creative Arts Project, um dos maiores projetos de arte na prisão do mundo.

${ }^{24}$ Caroline Vetori, doutoranda em Teatro pelo PPGT-UDESC.

${ }^{25}$ Naguissa Takemoto, Licenciada em Teatro pela UDESC.

${ }^{26}$ Hanna Agnew, estudante da Universidade de Michigan. 
uns jogos diferentes, bem lúdicos, que as alunas adoraram! Acho que, como a Ashley e a Hanna eram estrangeiras, as alunas se sentiram valorizadas e consequentemente passaram a valorizar ainda mais o curso de teatro também... até arriscaram umas palavras em inglês! E foi ótima a presença do pessoal da UDESC aqui, e também nossa visita posterior à aula de teatro com elas no Presídio Feminino em Florianópolis: foram trocas pedagógicas, mas também ações de fortalecimento institucional do teatro nas prisões. As conversas com as direções dos presídios, com as representantes do setor de educação da Secretaria de Administração Prisional e as contextualizações sobre os trabalhos realizados em distintas unidades prisionais e países auxiliaram no reconhecimento e consolidação destas práticas. Tomara que elas possam vir à apresentação final das nossas alunas!

Por falar nisso, acho que poderíamos investir no prazer das atividades que elas mais gostaram de realizar nesse semestre: os jogos e as canções! Que tal selecionarmos alguns jogos e canções que elas já conhecem, e fazermos uma colagem, com algumas músicas gravadas que já usamos em aulas também, criando as transições de cena? E podíamos utilizar a verba do projeto para comprar algumas roupas em brechó, que tal? Elas falaram diversas vezes o quanto sentem falta de vestir uma roupa normal, sem o laranja do uniforme da prisão. Se você achar a ideia interessante, podemos apresentar para elas no próximo encontro, e ver o que elas pensam. Precisamos também combinar com elas quem vamos convidar para assistir às apresentações. Seria ótimo que uma turma pudesse ver a outra... mas a direção do PRJ já disse que isso não será possível, por causa de algumas rivalidades internas. Acho que seria muito importante a presença da direção do presídio, da pastoral carcerária, do centro de direitos humanos e do juiz João Marcos Buch, pessoas que nos apoiaram e acompanharam nestes dez anos de projetos, do celas ao celas e elas. E também podíamos convidar o Vicente, a Carol e a Naguissa para assistirem à estreia delas! Acho que elas vão amar! O que me dizes?

Aguardo teu retorno e envio algumas fotos dos nossos encontros com elas para teu arquivo. 
Beijas e se cuida, Dai.

Figura 3 - Curso de Teatro no PRJ. 05 maio 2019. Foto: Jéssica Michels

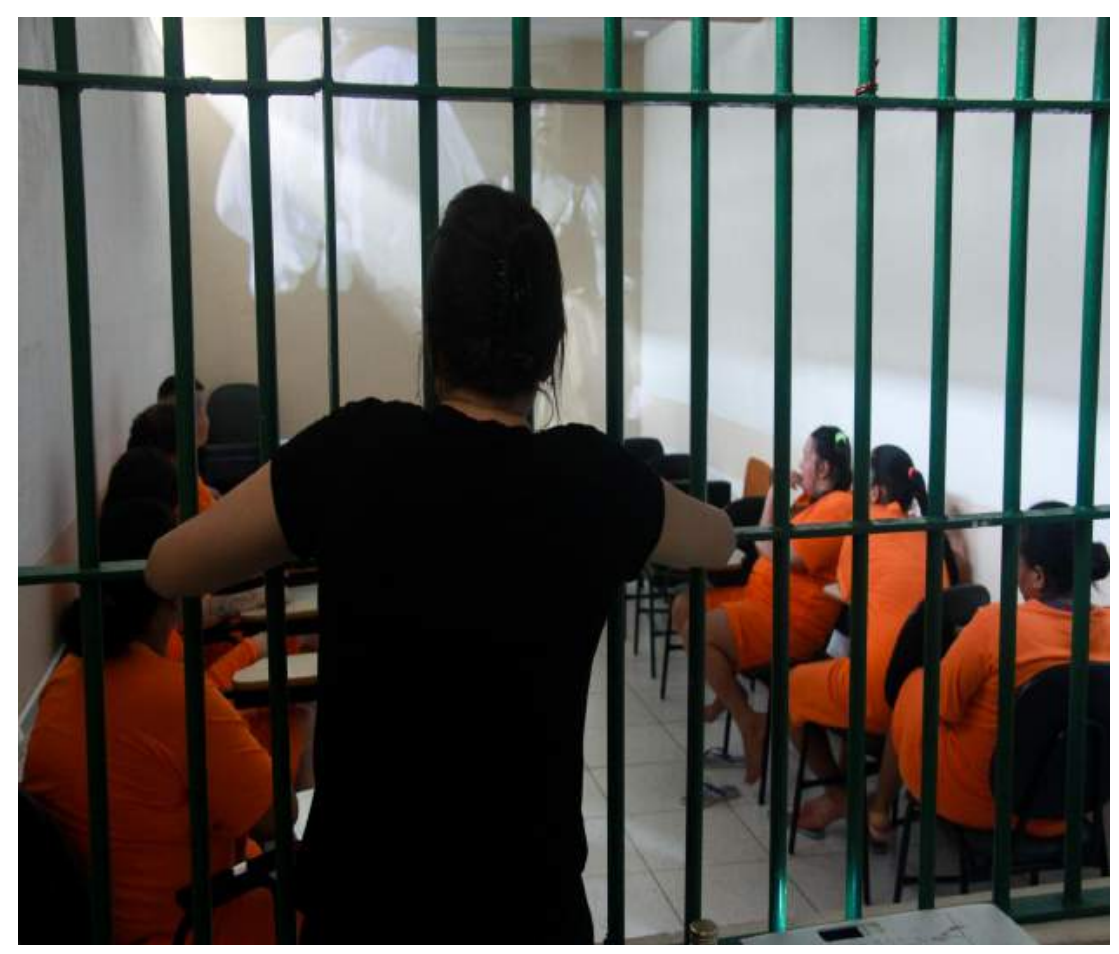

Figura 4 - Curso de Teatro no PRJ. 29 mar. 2019.

Foto: Jéssica Michels

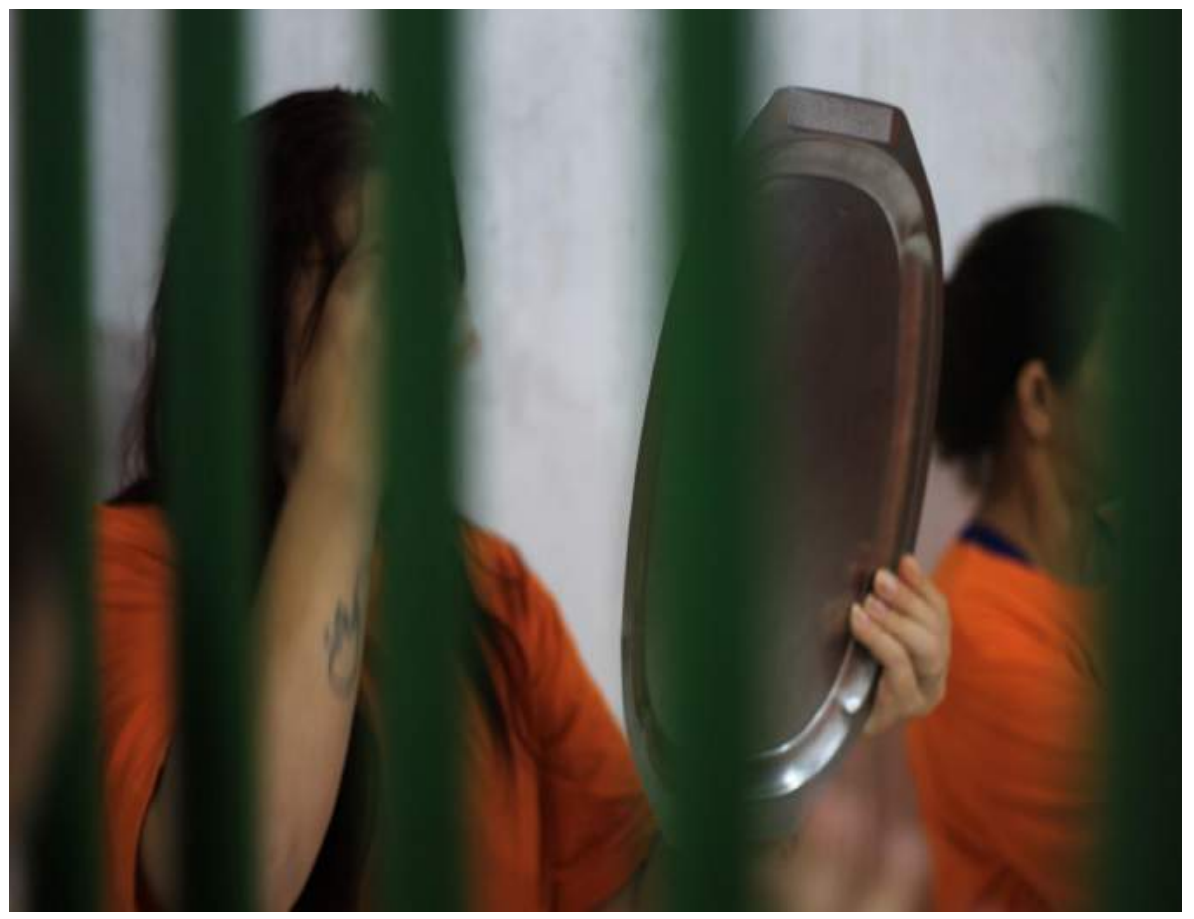


Carta das professoras-em-processo ${ }^{27}$ (ou./2020)

Queridas alunas,

Esperamos que esta carta lhes encontre bem e com saúde. Certamente isso é o mais importante neste momento em que estamos sendo atravessadas pela pandemia de Covid-19.

Como vocês sabem, o nosso curso de teatro deveria ter sido retomado no dia 27 de março deste ano ${ }^{28}$. Porém, devido às medidas de restrição de convívio decretadas pelo governo do Estado de Santa Catarina, necessárias para diminuir os índices de transmissão do vírus e preservar a saúde de todas, o curso teve que ser adiado. Vamos torcer para que em breve possamos superar esta pandemia e retomar as aulas!

Nós também estamos isoladas: Samira em casa com a família em Joinville, e Daiane em casa com a família em Florianópolis. Em casa, além das tarefas domésticas diárias, estamos trabalhando, lendo livros e escrevendo projetos, artigos e quando percebemos já é noite.

Samira aprendeu a bordar, mas sem sucesso. Então começou a praticar yôga e meditação para manter a mente, o corpo e o espírito sãos. Daiane está trabalhando dobrado em casa nas atividades da universidade. E quem está adorando são os gatos, que ficam com ela o dia todo!

Mesmo separadas, conseguimos exibir a filmagem da desmontagem celas e elas em uma mostra de teatro online ${ }^{29}$, aquela peça que apresentamos para vocês ano passado juntamente com a exposição de fotografias de nosso curso ${ }^{30}$,

27 Uma versão desta carta foi enviada às alunas do curso de teatro do PRJ no primeiro semestre de 2020, informando sobre o adiamento da retomada das aulas devido à pandemia de Covid-19.

28 Através do projeto Teatro para o desenvolvimento humano, aprovado no Edital Campus de Cultura da UDESC em 2019, Promovido pela Pró-Reitoria de Extensão, Cultura e Comunidade. O projeto é coordenado pela professora Dra. Cinara Terezinha Menegazzo, da UDESC Joinville, com a participação da professora Daiane Dordete da UDESC-CEART e da atriz Samira Sinara Souza.

29 Exibição da filmagem realizada na programação da 8o edição do Verão Teatral da AJOTE - Associação Joinvilense de Teatro, em abril de 2020.

${ }^{30}$ A exposição Para além das celas acompanha as apresentações da desmontagem teatral celas e elas, com 
lembram? Fizemos um bate papo ao vivo com um público de vinte e cinco pessoas. Tivemos pessoas do Rio de Janeiro, Argentina, Florianópolis, Joinville e São Paulo, e cada uma recebeu por e-mail uma das cartas que vocês escreveram durante nossas aulas... lembram dessas cartas? Elas registraram suas impressões sobre as aulas de teatro, os desejos de vida e as críticas às injustiças sociais e jurídicas... muito importantes para quem está de fora das grades refletir sobre o contexto que vocês vivenciam, e que carece de tanta atenção a direitos humanos e civis básicos. Obrigada mais uma vez por elas!

Foi uma experiência bem diferente essa de assistir uma filmagem de teatro e conversar com o público pela internet, mas o debate foi muito bacana, e as pessoas gostaram muito de saber que existem projetos de arte nas prisões, como esse, e de ler suas cartas e poder ouvir um pouco suas vozes também.

Este ano faríamos a circulação dessa desmontagem e da exposição em quatro regiões do Estado de Santa Catarina, através de um prêmio estadual que ganhamos ano passado ${ }^{31}$. As apresentações já estavam marcadas, e seriam realizadas em penitenciárias femininas e teatros de quatro cidades. Mas tivemos que adiar indefinidamente este projeto também, devido à pandemia.

A Samira, juntamente com um cineasta joinvilense, encaminhou um projeto para o Prêmio Catarinense de Cinema ${ }^{32}$ com objetivo de ofertar um curso de roteiro cinematográfico a vocês e às mulheres do Presídio de Florianópolis também. E o projeto foi...selecionado! A fotógrafa Jéssica, que vocês já conhecem, também está inserida neste projeto. Então, quando a pandemia passar, teremos muito o que conversar (e escrever!).

Nos despedimos aqui, aguardando ansiosas pela retomada de nossos encontros, e esperando que vocês estejam bem, na medida do possível. Deixamos

fotos do processo pedagógico realizado durante 2019 com mulheres do PRJ. As fotografias são de Jéssica Michels, e a curadoria é de Daiane Dordete, Jéssica Michels e Samira Sinara.

${ }^{31}$ Pelo Edital de Estímulo à Cultura Elisabete Anderle 2019. Projeto: [celas] e elas - circuito de apresentações e exposições. Proponente: Samira Sinara Souza.

32 Prêmio Catarinense de Cinema 2020. Projeto: Um olhar para o outro: curso de Roteiro com seres humanos em privação de liberdade. Proponente: Samira Sinara Souza. 
como lembrança algumas fotos de nossas aulas e do celas e elas, além da letra da Suite do Pescador, do Dorival Caymmi, que algumas vezes cantamos em aula, e que encerrou a apresentação de estreia de vocês no teatro. Já falamos isso várias vezes, mas é sempre bom lembrar: foram lindas as apresentações e vocês arrasaram como atrizes!

Por favor, não se esqueçam de nós, porque nós não vamos esquecer de vocês.

Abraços das professoras de teatro,

Daiane e Samira.

Minha jangada vai sair pro mar

vou trabalhar, meu bem querer

Se deus quiser quando eu voltar do mar um peixe bom eu vou trazer Meus companheiros também vão voltar e a deus do céu vamos agradecer Adeus, adeus

Pescador não esqueça de mim

Vou rezar pra ter bom tempo, meu bem

Pra não ter tempo ruim

vou fazer sua caminha macia

Perfumada com alecrim

Figura 5 - Curso de Teatro no PRJ. Apresentação final delas. 28 jun. 2019.

Foto: Jéssica Michels

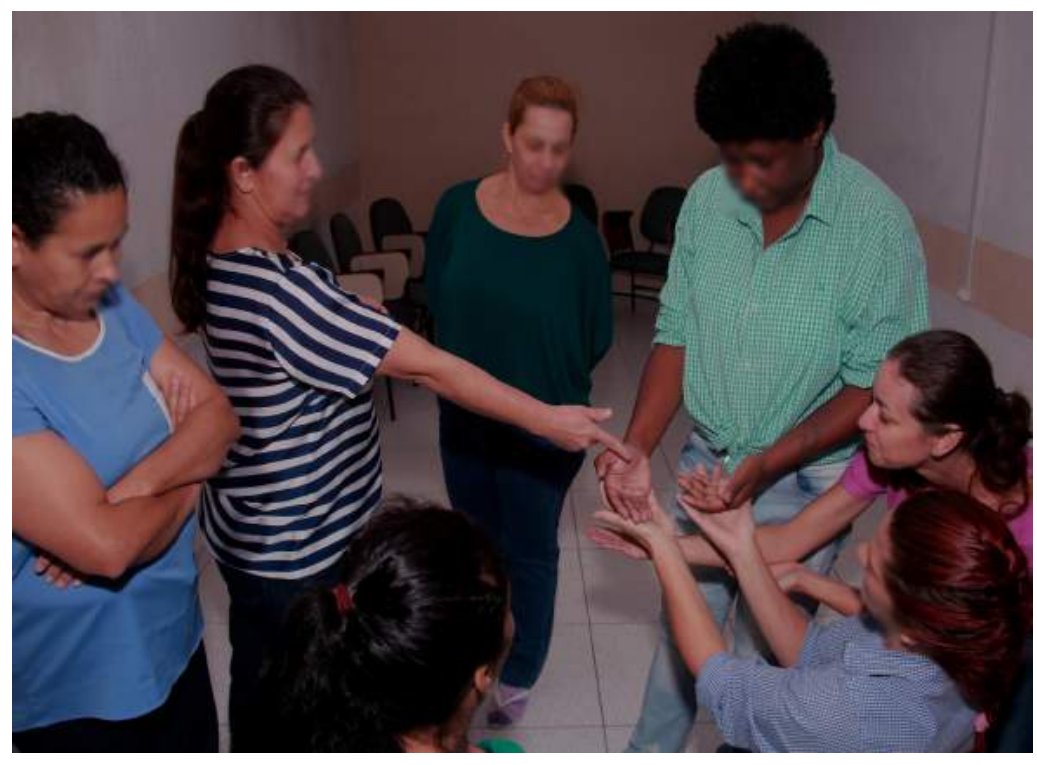


Figura 6 - Desmontagem celas e elas. Casa Iririú, Joinville, 28 jul. 2019.

Foto: Jéssica Michels

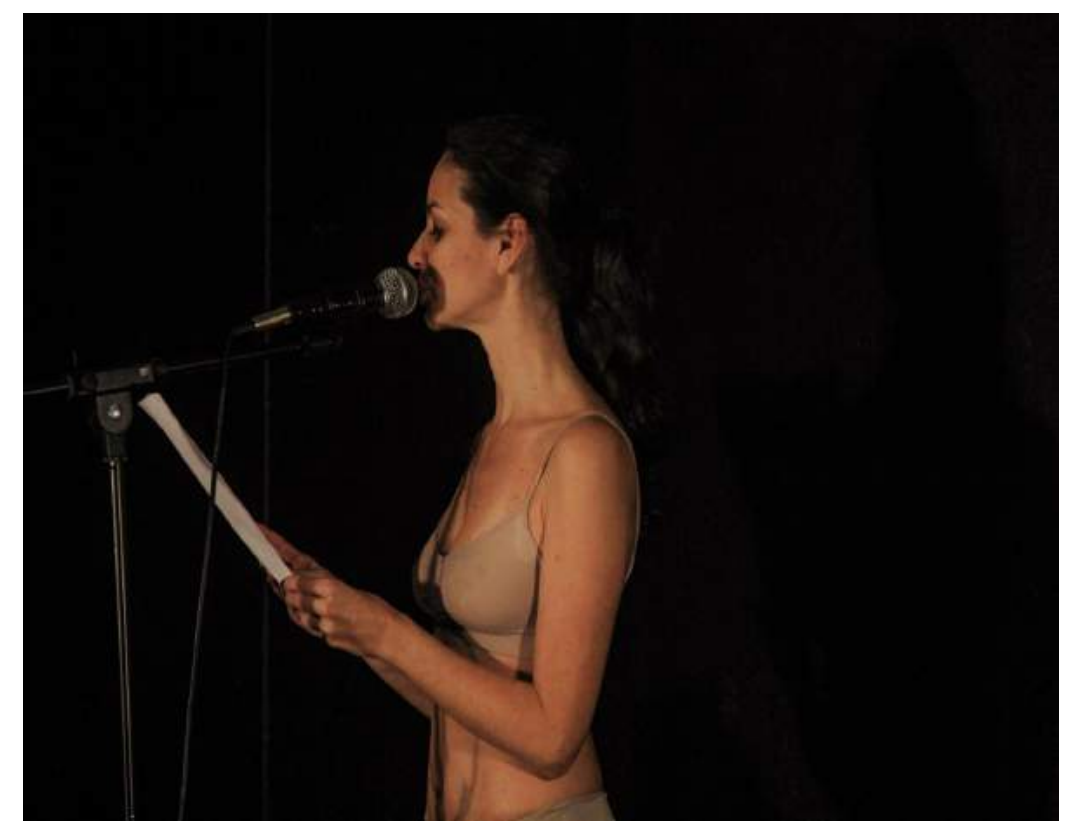

\section{Referências}

BERTH, Joice. O que é empoderamento? Belo Horizonte (MG): Letramento, 2018.

BOAL, Augusto. Jogos para atores e não atores. 13a. Ed. Rio de Janeiro: Civilização Brasileira, 2009.

BORGES, Juliana. Encarceramento em massa. 1a. reimpressão. São Paulo: Sueli Carneiro; Pólen, 2019.

CABRAL, Biange. O professor-artista: perspectivas teóricas e deslocamentos históricos. Urdimento, Florianópolis, v.1, n. 10, 2008.

CELAS Blogspot. Disponível em: <http://celaseelas.blogspot.com/>. Acesso em: 25 de set. 2020.

CERNEKA, Heidi Ann. Homens que menstruam: considerações acerca do Sistema Prisional às especificidades da Mulher. Veredas do Direito, Belo Horizonte, v. 6 n. 11 p. 61-78 Janeiro - Junho de 2009.

CERTEAU, Michel de. A invenção do cotidiano 1: artes do fazer. 10.ed. Petropólis: Vozes, 1994. 
COHEN, Renato. Work in progress na cena contemporânea: criação, encenação e recepção. São Paulo: Perspectiva, 2004.

JACOBS, Daiane Dordete Steckert. Celas (dramaturgia). Não publicada, 2011.

SPOLIN, Viola. Improvisação para o teatro. Tradução e revisão Ingrid Dormien Koudela e Eduardo José de Almeida Amos. São Paulo: Perspectiva, 2008.

TIROTTI, Nilton. A universidade leva à penitenciária. Blogspot. Disponível em: <http://tirotti.blogspot.com/>. Acesso em 01 de out.2020.

VINCENZO, Elza Cunha de. Um Teatro da Mulher: Dramaturgia feminina no palco brasileiro contemporâneo. São Paulo: Ed. Universidade de São Paulo, 1992.

Recebido em: 15/10/2020

Aprovado em: 26/10/2020 